\title{
Retrospective evaluation of candidemic patients among general surgery department in a tertiary care university hospital
}

\author{
Uğur Önal ${ }^{1}$, Dilek Yeşim Metin ${ }^{2}$, Can Karaca ${ }^{3}$, Süleyha Hilmioğlu Polat ${ }^{2}$, Sinan Ersin ${ }^{4}$, Meltem Işıkgöz Taşbakan ${ }^{1}$ \\ 1 Department of Infectious Diseases and Clinical Microbiology, Ege University School of Medicine, Izmir, Turkey \\ ${ }^{2}$ Department of Medical Microbiology, Ege University School of Medicine, Izmir, Turkey \\ ${ }^{3}$ Department of General Surgery, Izmir Economics University School of Medicine, Izmir, Turkey \\ ${ }^{4}$ Department of General Surgery, Ege University School of Medicine, İmir, Turkey
}

\section{ABSTRACT}

Objective: Candida species are among the most important causes of hospital acquired blood borne infections, and with high rates of mortality and morbidity, these infections are still a major problem today. History of gastrointestinal surgery, administration of total parenteral nutrition and/or wide spectrum antibiotics and immune suppression following organ transplantations are considered serious risk factors for these infections. This study aimed to evaluate the patients from our general surgery department with diagnosed candidemia; by means of strain, treatment and prognosis.

Material and Methods: Patients with positive blood cultures for Candida species who were treated in the wards and Ege University Faculty of Medicine general surgery department of surgical intensive care units of our between 2012 and 2017 were retrospectively analyzed by means of strain, treatment and prognosis.

Results: A total of 50 patients were enrolled in the study. Mean age was 58.96 years and $54 \%$ of the patients were female. There were nine patients with organ transplantation (four liver and five kidney transplantations), six with intestinal perforation and three with anastomotic leakage. Isolated strains were Candida albicans (36\%; 18/50), Candida tropicalis (14\%; 7/50), Candida glabrata (12\%; 6/50), Candida parapsilosis (8\%; 4/50), Candida kefyr (6\%; $3 / 50)$, Candida krusei (4\%; 2/50), Candida pulcherrima (2\%; 1/50), Cryptococcus neoformans (2\%, 1/50), Geotrichum capitatum (2\%, $1 / 50)$, Candida spp. (unidentified, 14\%; 7/50) with decreasing frequency. The highest antifungal sensitivity rates (>90\%) were measured for amphotericin B, voriconazole and echinocandins among all isolates. One-month mortality rate was 43.4\% (20/46). Documented eradication was achieved among 24 of the 33 patients who had control blood culture samples (72.7\%), and mean eradication time was 7.6 days. Echocardiography was performed in $14 \%(7 / 50)$ and ophthalmic examination in $8 \%(4 / 50)$.

Conclusion: Although C. albicans appears to be the dominant strain in patients with candidemia, frequencies of other strains are increasing. Early diagnosis and treatment of patients with candidemia is of vital importance due to high mortality and morbidity rates.

Keywords: Candidemia, prognosis, treatment, risk factors

Cite this article as: Önal U, Metin DY, Karaca C, Hilmioğlu Polat S, Ersin S, Işıkgöz Taşbakan M. Retrospective evaluation of candidemic patients among general surgery department in a tertiary care university hospital. Turk J Surg 2019; 35 (3): $210-213$

\section{Corresponding Author}

Uğur Önal

E-mail:uonal05@gmail.com

Received: 20.06 .2018

Accepted: 10.10 .2018

Available Online Date: 23.09.2019

O Copyright 2019 by Turkish Surgical Society Available online at www.turkjsurg.com

DOI: 10.5578/turkjsurg.4252

\section{INTRODUCTION}

Candidemia demonstrated as an important part of invasive fungal infections and also a significant factor for the high mortality rates, prolonged length of hospital stay and high health-related costs, ranks between the fourth and seventh mostly seen disease among the blood stream infections in the United States and Europe (1). Candidemia incidence has been shown as 1.23 to 12.3 per 1000 admissions from our country which can be varied due to regional differences in terms of mortality rates, isolated pathogens, risk factors and antifungal susceptibility rates (2-5).

This study aimed to evaluate the pathogens, treatments and prognosis of the patients followed by the General Surgery Department of our hospital.

\section{MATERIAL and METHODS}

In our study, the patients with positive blood cultures for Candida who were followed up by the Ege University Faculty of Medicine, General Surgery Department (Inpatient Clinic/Intensive Care Unit/Transplantation Unit) between the years of 2012-2017 were evaluated in terms of pathogen, treatment and prognosis, retrospectively. At least one positive blood culture for Candida spp. was accepted as candidemia and only adult patients ( $\geq 18$-year-old) were included into our study. Sociodemographic features, risk factors, blood culture results, 30-day (due to all causes) mortality rates and antifungal treatment regimens were screened via the 
patients' files. Sabouraud dextrose agar (Acumedia; Michigan, USA) was used for the culture, and identification of the species was performed by conventional methods (Dalmou method) with micromorphologic features, ID32C (bioMerieux; France) with carbohydrate assimilation features and MALDI-TOFF MS with proteomic features. Antifungal susceptibilities were investigated via E-test method, and minimum inhibitor concentration levels were used according to the CLSI guideline $(6,7)$.

Statistical Package for Social Sciences (SPSS) version 22.0 (IBM Corp.; Armonk, NY, USA) program was used to analyze our data. $P$ value below 0.05 was accepted as statistically significant.

No ethics committee approval was sought due to the retrospective design of the study. Our study was performed in accordance to the ethical standards of the Helsinki Declaration which was accepted by the World Health Community in 1975 (revised in 2008).

\section{RESULTS}

A total number of 50 patients ( $54 \%$ female) were recorded during the six-year period. Mean age was $58.96 \pm 2.36$ years. Comorbidities were recorded as nine organ transplantations (four liver transplantation, five renal transplantation), six intestinal perforations, four intraabdominal abscesses, and three anastomosis leakages (Table 1). Parenteral nutrition rate was 88\% (44/50).

Isolated pathogens from the blood cultures were Candida albicans (36\%; 18/50), Candida tropicalis (14\%; 7/50), Candida glabrata $(12 \% ; 6 / 50)$, Candida parapsilosis (8\%; 4/50), Candida kefyr (6\%; $3 / 50)$, Candida krusei (4\%; 2/50), Candida pulcherrima (2\%; 1/50), Cryptococcus neoformans (2\%, 1/50), Geotrichum capitatum (2\%, 1/50) , Candida spp. (14\%; 7/50), respectively (Figure 1).

The highest sensitivity rate (>90\%) among all isolates was observed for amphotericin B, voriconazole, caspofungin and echinocandin. Fluconazole resistance was investigated among the antifungal susceptibility tested ones, and resistance rate was observed as 2/16 (12.5\%) for both C. albicans and non albicans isolates. Fluconazole resistance was observed one out of three antifungal sensitivity tested C. glabrata isolates, which supports the fact that fluconazole resistance rate is increasing globally among them in recent years.

\section{Table 1. Comorbidities}

\begin{tabular}{|l|c|}
\hline Comorbidities & Rates (n, \%) \\
\hline Organ transplantation & $9(18 \%)$ \\
\hline Renal transplantation & $5(10 \%)$ \\
\hline Liver transplantation & $4(8 \%)$ \\
\hline Intestinal perforation & $6(12 \%)$ \\
\hline Intraabdominal abscess & $4(8 \%)$ \\
\hline Anastomosis leakage & $3(6 \%)$ \\
\hline
\end{tabular}

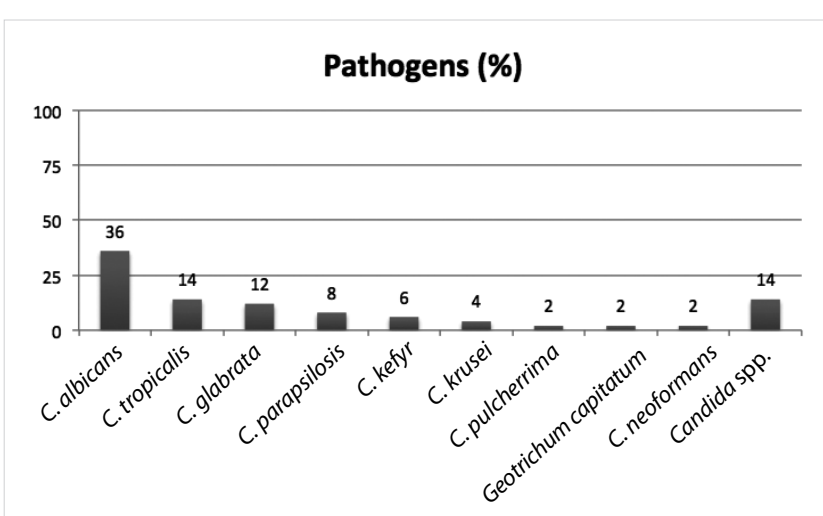

Figure 1. Pathogens.

A total number of four patients were discharged or transported to another hospitals, and thus the rest of the patients' all-cause mortality rate (for one month) was noted as 43.4\% (40/46). Antifungal treatment was not started in nine patients and mortality was observed in five. Four patients, in whom antifungal treatment was not started, were discharged or transported, and hence their follow up cannot been done. In subgroup analysis of different treatment regimens, mortality (one-month) rates were recorded as $(5 / 9 ; 55.6 \%)$ for fluconazole, $(8 / 27 ; 29.6 \%)$ for anidulafungin, $(1 / 3 ; 33.3 \%)$ for caspofungin, $(1 / 1 ; 100 \%)$ and $(0 / 1,0 \%)$ for liposomal amphotericin B plus fluconazole, respectively. Mortality rate (one-month) was found as statistically significant for the anidulafungin treatment given and non-given group (8/27$12 / 19 ; p=0.024$ ).

Treatment was changed in five patients (anidulafungin treatment was changed in four and fluconazole treatment was changed in one patient), and among them, only one mortality was observed whose treatment was switched to liposomal amphotericin B from fluconazole.

Microbiologic eradication was noticed in 24/33 patients whose control cultures were performed with a mean duration of 7.6 days. Mortality rate (one-month) was found as statistically significant for the microbiologic responsive and nonresponsive group (4/24-7/9; $p=0.002)$.

Mean duration of treatment was noted as $17.9 \pm 2.26$ (min 1 , max 58 days) in the treatment given patients. Echocardiography was performed in $14 \%(7 / 50)$ and ophthalmoscopic examination was done in $8 \%(4 / 50)$ during the follow up period of candidemia patients. Infective endocarditis was spotted in one out of seven patients via echocardiography, and none of the four patients had septic emboly in whom ophthalmoscopic examination was carried out.

\section{DISCUSSION}

Although the mostly seen pathogen is C. albicans in candidemia patients, the incidence of non-albicans Candida isolates has increased in recent years $(1-3,13)$. Urethral catheterization, 
total parenteral nutrition, history of wide spectrum antibiotic usage, blood transfusion, central venous catheters are accepted as the important risk factors for candidemia (8). In our study, although the mostly detected pathogen was C. albicans (36\%) in candidemia patients similar to the literature data, non-albicans Candida was also seen with high numbers (50\%). History of gastrointestinal surgery, total parenteral nutrition, organ transplantation and immunosupression were the main risk factors for candidemia in our study.

In recent years, fluconazole resistance is seen in high rates for non-albicans Candida spp. like C. glabrata besides the natural resistant C. krusei, and Mencarini et al. have shown fluconazole resistance rate as $30 \%$ for C. glabrata from Italy (9). In our study, although the numbers were low, we found fluconazole resistance as $33 \%$ similar to the literature thus, we believe that echinocandins should be preferred to fluconazole in candidemia patients with C. glabrata.

Karadag et al. have revealed a mortality rate as 30\% for a total number of 89 candidemia patients from our country (10). Different mortality rates have been seen in the literature from our country like Kocak et al. who have confirmed a mortality rate as high as 58\% for 38 candidemia patients (11). In our study, onemonth mortality rate with all causes was spotted as $43.4 \%$ for 46 followed-up patients. Antifungal treatment was not started in nine patients, and mortality was observed as $100 \%$ in the rest of the four patients who were discharged or transported to other hospitals (5/5). These results also show that early diagnosis and treatment for candidemia patients are vitally important due to high mortality rates. In subgroup analysis, mortality rate (one-month) was found as statistically significant for the anidulafungin treatment given and non-given group (8/27-12/19; $p=$ 0.024).

Five main subjects underlined to increase survival rates in candidemia patients are appropriate antifungal treatment, control blood culture follow-up, echocardiography control, ophthalmoscopic examination and removal of central venous catheter, respectively (12). Another important result of our study revealed that echocardiography and ophthalmoscopic examination were performed only in 14\% (7/50) and 8\% (4/50) of the candidemia patients.

The most important limitations of the study included its retrospective design and the fact that antifungal susceptibility test could not be performed in all samples.

\section{CONCLUSION}

In conclusion, appropriate antifungal treatment has a vital importance in candidemia patients due to high mortality rates despite the current diagnostic and therapeutic options. Although the mostly seen pathogen is C. albicans in candidemia patients, the incidence of non albicans Candida isolates is increasing. Due to high resistance for fluconazole, we believe that echinocandins like anidulafungin are more appropriate choices of antifungal treatment rather than fluconazole especially for the hemodynamically unstable intensive care unit patients. In addition to this, echocardiography and ophthalmoscopic examination should be kept in mind for the follow-up of candidemia patients.

Ethics Committee Approval: No ethics committee approval was sought due to the retrospective design of the study.

Informed Consent: Due to the retrospective design of the study, the informed consent was not obtained.

Peer-review: Externally peer-reviewed.

Author Contributions: Consept - U.Ö., M.I.T.; Design - U.Ö.; Supervision M.I.T., Resource - D.Y.M., S.H.P., C.K., S.E., Materials - D.Y.M., S.H.P.; Data Collection and/or Processing - U.Ö., D.Y.M.; Analysis and Interpretation - U.Ö.; Literature Search - U.Ö.; Writing Manuscript - U.Ö.; Critical Reviews - M.I.T., D.Y.M.

Conflict of Interest: The authors have no conflicts of interest to declare.

Financial Disclosure: The authors declared that this study has received no financial support.

\section{REFERENCES}

1. Antinori S, Milazzo L, Sollima S, Galli M, Corbellino M. Candidemia and invasive candidiasis in adults: a narrative review. Eur J Intern Med 2016; 34:21-8. [CrossRef]

2. Kazak E, Akın H, Ener B, Sığırlı D, Özkan Ö, Gürcüoğlu E, et al. An investigation of Candida species isolated from blood cultures during 17 years in a university hospital. Mycoses 2014; 57: 623-9. [CrossRef]

3. Alp S, Arikan-Akdagli S, Gulmez D, Ascioglu S, Uzun O, Akova M. Epidemiology of candidaemia in a tertiary care university hospital: 10-year experience with 381 candidaemia episodes between 2001 and 2010. Mycoses 2015; 58: 498-505. [CrossRef]

4. Yeşilkaya A, Azap Ö, Aydın M, Akçil Ok M. Epidemiology, species distribution, clinical characteristics and mortality of candidaemia in a tertiary care university hospital in Turkey, 2007-2014. Mycoses 2017; 60: 433-9. [CrossRef]

5. Yapar N, Akan M, Avkan-Oguz V, Ergon CM, Hancer M, Doluca M. Risk factors, incidence and outcome of candidemia in a Turkish intensive care unit: a five-year retrospective cohort study. Anaesth Pain \& Intensive Care 2014; 18: 265-71.

6. Clinical and Laboratory Standards Institute. Reference Method for Broth Dilution Antifungal Susceptibility Testing of Yeasts; Approved Standard-Third Edition. M27A3, 2008.

7. Cuenca-Estrella M, Verweij PE, Arendrup MC, Arikan-Akdagli S, Bille J, Donnelly JP, et al. ESCMID** *This guideline was presented in part at ECCMID 2011. European Society for Clinical Microbiology and Infectious Diseases. Guideline for the diagnosis and management of candida diseases 2012: diagnostic procedures. Clin Microbiol Infect 2012; 18 (Suppl 7): 9-18. [CrossRef]

8. Yapar N, Pullukcu H, Avkan-Oguz V, Sayin-Kutlu S, Ertugrul B, Sacar S, et al. Evaluation of species distribution and risk factors of candidemia: a multicenter case-control study. Med Mycol 2011;49: 26-31. [CrossRef] 
Mencarini J, Mantengoli E, Tofani L, Riccobono E, Fornaini R, Bartalesi F, et al. Evaluation of candidemia and antifungal consumption in a large tertiary care Italian hospital over a 12-year period. Infection 2018; 46: 469-76. [CrossRef]

10. Karadağ FY, Ergen P, Aydın Ö, Doğru A, Tanıdır B, Vahaboğlu MH. Evaluation of epidemiological characteristics and risk factors affecting mortality in patients with candidemia. Turk J Med Sci 2016: 20; 46: 1724-8. [CrossRef]
11. Koçak BY, Kuloğlu F, Doğan Çelik A, Akata F. Evaluation of epidemiological characteristics and risk factors of candidemia in adult patients in a tertiary-care hospital. Mikrobiyol Bul 2011; 45: 489-503.

12. Murri R, Giovannenze F, Camici M, Torelli R, Ventura G, Scoppettuolo $G$, et al. Systematic clinical management of patients with candidemia improves survival. J Infect 2018; 77: 145-50. [CrossRef]

13. Kostakoğlu U, Yılmaz G, Köksal I. Fungal infections; species distribution and treatment response. FLORA 2018; 23: 73-8. [CrossRef]

\title{
ORIJINAL ÇALIŞMA-ÖZET
}

Turk J Surg 2019; 35 (3): 210-213

\section{Bir üçüncü basamak tıp fakültesi hastanesi genel cerrahi bölümünde takip edilen kandidemili olguların retrospektif değerlendirilmesi}

\author{
Uğur Önal ${ }^{1}$, Dilek Yeşim Metin ${ }^{2}$, Can Karaca ${ }^{3}$, Süleyha Hilmioğlu Polat ${ }^{2}$, Sinan Ersin ${ }^{4}$, Meltem Işıkgöz Taşbakan ${ }^{1}$ \\ 1 Ege Üniversitesi Tıp Fakültesi, Enfeksiyon Hastalıkları ve Klinik Mikrobiyoloji Anabilim Dalı, İzmir, Türkiye \\ ${ }^{2}$ Ege Üniversitesi Tıp Fakültesi, Tıbbi Mikrobiyoloji Anabilim Dalı, İzmir, Türkiye \\ ${ }^{3}$ İzmir Ekonomi Üniversitesi Tıp Fakültesi, Genel Cerrahi Anabilim Dalı, İzmir, Türkiye \\ ${ }^{4}$ Ege Üniversitesi Tıp Fakültesi, Genel Cerrahi Anabilim Dalı, İzmir, Türkiye
}

\section{ÖZET}

Giriş ve Amaç: Candida türleri, hastane kaynaklı kan yoluyla bulaşan enfeksiyonların başlıca sebepleri olmakla birlikte yüksek oranda morbidite ve mortalite sebebiyle günümüzde hala bir sorun teşkil etmektedir. Gastrointestinal cerrahi işlemi öyküsü, total parenteral beslenme ve/veya geniş-spektrumlu antibiyotik kullanımı ve organ transplantasyonu sonrası immünsüpresyon bu enfeksiyonlar için risk ciddi risk faktörleri olarak kabul edilmektedir. Bu çalışmada genel cerrahi bölümümüzde kandidemi tanısı almış hastaların suş, tedavi ve prognoz açısından değerlendirilmesi amaçlanmıştır.

Gereç ve Yöntem: 2012-2017 yılları arasında Ege Üniversitesi Tıp Fakültesi Genel Cerrahi servisinde veya yoğun bakım ünitesinde tedavi gören ve kan kültürlerinde Candida türleri bulunan hastalar retrospektif olarak suş, tedavi ve prognoz açısından değerlendirildi.

Bulgular: Çalışmaya toplamda 50 hasta dahil edildi. Ortalama yaş 58.96 ve hastaların \%54'ü kadındı. Organ transplantasyonu geçirmiş dokuz hasta vardı (dört karaciğer, beş böbrek transplantasyonu), altı hastada intestinal preforasyon ve üçünde anastomoz kaçağı tespit edildi. Izole edilen suşlar sıklığı azalan şekilde sırasıyla Candida albicans (\%36; 18/50), Candida tropicalis (\%14; 7/50), Candida glabrata (\%12; 6/50), Candida parapsilosis (\%8; 4/50), Candida kefyr (\%6; 3/50), Candida krusei $(\% 4 ; 2 / 50)$, Candida pulcherrima $(\% 2 ; 1 / 50)$, Cryptococcus neoformans (\%2, 1/50), Geotrichum capitatum $(\% 2,1 / 50)$, Candida spp. (tanımlanamayan, \%14; 7/50) idi. Tüm suşlar arasında en yüksek antifungal duyarlılık oranları (> \%90) amfoterisin B, vorikonozol ve ekinokandinler için ölçüldü. Bir aylık mortalite oranı \%43,4 (20/46) olarak bulundu. Belgelenmiş eradikasyon, kontrol kan örneği olan 33 hastadan $24(\% 72,7)$ 'ünde elde edildi ve ortalama eradikasyon süresi 7,6 gündü. Ekokardiyografi ve oftalmik muayene sırasıyla \%14 (7/50) ve \%8 (4/50) hastada uygulandı.

Sonuç: Kandidemi hastalarında en dominant tür C. albicans olsa da, diğer suşların sıklığı da artmaktadır. Erken tanı ve kandidemi hastalarının tedavisi yüksek mortalite ve morbidite oranları açısından büyük öneme sahiptir.

Anahtar Kelimeler: Kandidemi, prognoz, tedavi, risk faktörleri

Doi: $10.5578 /$ turkjsurg. 4252 